\title{
Blue light evoked by LED, pc screens, TV or sun rays trespassing the hole of ozone layer is fatal for skin health in Man: rhodopsins from animals or some algae represent a touchesane to exorcize this dramatic concern
}

\author{
Piotr Brzeziński', Lorenzo Martini ${ }^{1,2}$
}

\begin{abstract}
${ }^{1}$ Institute of Biology and Environmental Protection, Pomeranian Academy, Slupsk, Poland, ${ }^{2}$ Department of Dermatology, $6^{\text {th }}$ Military Support Unit, Ustka, Poland, ${ }^{3}$ Department of Excellence of Biotechnologies, Pharmacy and Chemistry, University of Siena, Siena, Italy, ${ }^{4}$ Interuniversity Centre for researches Advanced Medical Systems, University of Siena
\end{abstract}

Corresponding author: Prof. Lorenzo Martini, E-mail: martini174@virgilio.it

\begin{abstract}
Blue light belongs to the visible rays that everyday reach our planet trespassing the barrier of the ozone layer that is more and more thinner and lacking of consistency. Blue light is emitted even from manifold technological apparatuses like smartphones, TV, pc screen or all kinds of LED lamps (used in fashion défilés, and in manufacturing industries etc) and this type of light is exceptionally risky for all human skin (degradation and necrosis of collagen and elastin till malignant melanoma in black-skin persons). Some rhodopsins extracted enzymatically or physically or chemically from crabs or divers algae, undergo the phenomenon of bleaching when treated with $\mathrm{NH}_{2} \mathrm{OH}$. But, when they are not treated with this alkali, the rhodopsins continue to absorb the blue (and not the green or purple light) and these types of rhodopsins may be disperded in a special oleolite made of ciclosiloxane in order to protect delicate skins or skins that are prone to senescence of occurrence of melanomas.
\end{abstract}

Key words: Clamydomonas; Cancer pagarus; LED; Ciclosiloxane 345; Skin senescence; Malignant melanoma

\section{INTRODUCTION}

The research on blue light isn't as advanced as the research on UV, so we don't know anywhere near as much about how exactly it causes damage to skin.

And to make it more confusing, older studies on the effects of blue and violet light aren't as valid. A lot of the time the lights used in the studies also produced UV, so it's possible that the effects they found were from the contaminating UV rays and not the visible light at all and even very small amounts of UVAl $(0.5 \%)$ can work synergistically with visible light in causing its effects.

In Caucasian individuals and albinos Blue light decelerate dramatically the cell turnover encouraging the cutaneous senescence.
In hyperpigmented people (Asians and Black skinned persons) Blue light may drive to the occurrence of malignant melanoma, to boot.

Besides all the radiations characterized by low frequence and highest wavelength ( $\gamma$-rays and $\mathrm{X}$-rays) are extremely rich of energy and are capable to trespass the barrier of the ozone layer and can evoke irreversible damages to all the living organisms and in Man on the skin in toto.

Blue, green and purple light (some of the visible radiations) may trespass the ozone layer and invade the circumstantial atmosphere, where we live, as the aforesaid ionizing rays.

In another future seat the AA will discuss the concern about the risk of the incidence of ionizing rays on the

\footnotetext{
How to cite this article: Brzeziński P, Martini L. Blue light evoked by LED, pc screens, TV or sun rays trespassing the hole of ozone layer is fatal for skin health in Man: rhodopsins from animals or some algae represent a touchesane to exorcize this dramatic concern. Our Dermatol Online. 2019;10(e):e28.1-e28.3.

Submission: 05.07.2019; Acceptance: 12.08.2019

DOI: 10.7241 /ourd. $2019 \mathrm{e} .28$
} 
human metabolism and will attempt to find some peculiar natural or organic ingredients apt to protect skin from all these rays (idest micronized malakite, Copper PCA or Gold zeolite micronized).

In this paper the AA desire to propose the usage of rhodopsins extracted from animals (crabs) or algae (Clamydomomnas).

In cosmetics all the following algae are allowed to be inserted in beauty formulas for skin care for women and men: AFA, Algae, Algas Verdiazul, Algues BleuVert, Algues Bleu-Vert du Lac Klamath, Anabaena, Aphanizomenon flos-aquae, Arthrospira maxima, Arthrospira platensis, BGA, Blue Green Algae, BlueGreen Micro-Algae, Cyanobacteria, Cyanobactérie, Cyanophycée, Dihe, Espirulina, Hawaiian Spirulina, Klamath, Klamath Lake Algae, Lyngbya wollei, Microcystis aeruginosa, Microcystis wesenbergii, Nostoc ellipsosporum, Spirulina Blue-Green Algae, Spirulina Fusiformis, Spirulina maxima, Spirulina platensis, Spirulina pacifica, Spiruline, Spiruline d'Hawaii, Tecuitlatl.

Rhodopsins are membrane receptor proteins which use a light absorbing chromophore to capture the light and as a consequence of light absorption gain enzymatic activity. Rhodopsins are found in bacteria; archaea; eukaryotes such as Peranema (a euglenoid) [1], Chlamydomonas (a green alga) [2], Allomyces (a chytrid motile fungus) [3]; and animals. The existence of similar conserved amino acids in all rhodopsins in the region surrounding the chromophore [4] indicates the likelihood of common or at least similar mechanisms of rhodopsin activation [5].

The methods of extraction are enzymatic and physical and in the plot the two kinds of substrates have been treated to yield pure rhodopsins (Table 1).

Rhodopsins were exposed to green light $(\mathrm{OE} ; 550 \mathrm{~nm}$; $409 \mathrm{~W} / \mathrm{cm}^{2}$ ), to blue light (E; $\left.403 \mathrm{~nm} ; 300 \mathrm{~W} / \mathrm{cm}^{2}\right)$, or to blue light in the presence of $\mathrm{NH}_{2} \mathrm{OH}$ to inhibit potential photoreversal of bleaching (F; $403 \mathrm{~nm}$; $300 \mathrm{~W} / \mathrm{cm}^{2}$ ). Rhodopsin disappeared rapidly in green light and in blue light with $\mathrm{NH}_{2} \mathrm{OH}$, conditions with minimized photoreversal of bleaching. However, in blue light without $\mathrm{NH}_{2} \mathrm{OH}$, rhodopsin disappeared slowly, despite irradiation with the same photon fluxes as in the other two conditions.

These rhodopsins that were not treated with $\mathrm{NH}_{2} \mathrm{OH}$ were transeferred in a jar and disperded in Cyclosiloxane
Table 1: Informations about the two kinds of substrates have been treated to yield pure rhodopsins

\begin{tabular}{llc}
\hline Substrate & $\begin{array}{l}\text { Type of extraction } \\
\text { process }\end{array}$ & $\begin{array}{c}\text { Rhodopsin } \\
\text { yield }\end{array}$ \\
\hline Cancer pagarus & $\begin{array}{l}\text { Enzymatic and physisal: } \\
\text { א-carrageenase, } \\
\beta \text {-agarase, xylanase, } \\
\text { cellulase and Potter } \\
\text { ultracentrifugation with } \\
\text { deionised water }\end{array}$ & $11.57 \pm 0.08 \mathrm{~g} / 100$ \\
& Chemical: $0.4 \mathrm{HCl}$ & \\
$\begin{array}{l}\text { Clamydomonas } \\
\text { reinhardtii }\end{array}$ & & $59.76 \%$ yield \\
\hline
\end{tabular}

345 Dow Corning, in order to obtain a lotion to be spread on the skin.

The AA have studied deeply the concern about the capacity of rhodopsins both from Cancer pagarus and Clamydomonas reinhardtii to absorb blue light, but we must keep on account that blue light may come from every technological apparatus (computer screen, tv and the minimal quote of rays that trespass the ozone layer together with the ionizing radiations during all the hour of whichever day, in winter or summer and when it rains or it is cloudy).

\section{MATERIALS AND METHODS}

The AA have ideated the following sort of oleolite made of silicones and rhodopsins extract in n-propanolol.

$0.8 \%$ of rhodopsines (the ones from the crab treated enzymatically and physically and the ones treated chemically in acidic milieu in order to obtain a protein and polysaccharide degradation) is disperded in Cyclosiloxane 345 Dow Corning Chemical and spread on the faces and necks of 5 volunteers:

3 albinos: (we must remark that albinos are requested to walk on a city park all the day long, exposing themselves to sun rays): a) 21 y. old; b) 43 y. old; c) 58 y. old; d) a pale young mannequin ( $22 \mathrm{y}$. old) who had to walk on catwalk during fashion défilés under strong LED lights and who showed every evening a reddish and blistered skin especially on cheekbones 8after 7-8-9 hours of work); e) an employee of IRS (37 y. old) who uses to stay 8-9 hours in front of his pc cause of his job.

\section{RESULTS}

All volunteers had prior answered to a questionnaire (University of Rochester Medical Center) about the degree of inflammation due to aggression by sun rays during all the hours of daylight. 
Table 2: Values referred by volunteers after exposure to ray sun (the 3 albinos) or 8-9 hours of LED light (Case d) or 9 hours of standing in front of a pc (Case e), without spreading the oleolite containing rhodopsines

\begin{tabular}{lc}
\hline Case & $\begin{array}{c}\text { Score of burning feeling } \\
\text { (University of Rochester) }\end{array}$ \\
\hline A & 27 \\
B & 22 \\
C & 19 \\
D & 29 \\
E & 17 \\
\hline
\end{tabular}

Table 3: Values referred by volunteers after exposure to ray sun (the 3 albinos) or 8-9 hours of LED light (Case d) or 9 hours of standing in front of a pc (Case e), after having spread the oleolite containing rhodopsines

\begin{tabular}{lc}
\hline Case & $\begin{array}{c}\text { Score of burning feeling } \\
\text { (University of Rochester) }\end{array}$ \\
\hline A & 5 \\
B & 3 \\
C & 2 \\
D & 11 \\
E & 6 \\
\hline
\end{tabular}

Evaluations are measured with scores starting from 0 (no sun exposure) to 32 (the response of sun irradiation of Aborigens and Hispanics).

In Table 2 it is possible to observe the different scores recorded in the 5 volunteers after 9 hour of exposure to blue light for one entire day of work or rest without the usage of the oleolite containing rhodopsis and in Table 3 it is possible to behold the scores recorded in the same 5 volunteers after 9 hours of exposure to blue light after having applied the oleolite.

\section{DISCUSSIONS}

It is quite amazing to notice that Case e does not burn easily standing in front of his pc without spreading the oleolite (score 17) but one can observe that applying the lotion, the score disminishes drastically [6] and this means that pc screen releases blue light less than other sources as sun or LED [6-10].

\section{AKNOWLEDGEMENTS}

All these experiments have been possible to be done owing to the chance to use the laboratories and the machines of the Department of Excellence of Pharmaceutical Biotechnologies of the University of Siena.

\section{REFERENCES}

1. Foster KW, Saranak J, Dowben PA. Spectral sensitivity, structure, and activation of eukaryotic rhodopsins: activation spectroscopy of rhodopsin analogs in Chlamydomonas. J Photochem Photobiol Bio. 1991;8:385-408.

2. Foster KW, Saranak J, Derguini F, Jayathirtha Rao V, Zarrilli GR, Okabe M, et al. Rhodopsin activation: a novel view suggested by in vivo Chlamydomonas experiments. J Am Chem Soc. 1988;110:6588-9.

3. Foster KW, Saranak J, Derguini F, Zarrilli GR, Johnson R, Okabe M, et al. Activation of Chlamydomonas rhodopsin in vivo does not require isomerization of retinal. Biochemistry. 1989;28:819-24.

4. Foster KW, Saranak J, Patel N, Zarrilli G, Okabe M, Kline T, et al. A rhodopsin is the functioning photoreceptor for phototaxis in the unicellular eukaryote Chlamydomonas. Nature. 1984;311:7567-759.

5. Nygaard R, Valentin-Hansen L, Mokrosinski J, Frimurer TM, Schwartz TW. Conserved water-mediated hydrogen bond network between TM-I, -II, -VI, and -VII in 7TM receptor activation. J Biol Chem. 2010;285:19625-36.

6. Okada T, Sugihara M, Bondar A-N, Elstner M, Entel P, Buss V. The retinal conformation and its environment in rhodopsin in light of a new $2.2 \AA$ crystal structure. J Mol Biol. 2004;342:571-83.

7. Okada Y, Fujiyoshi Y, Silow M, Navarro J, Landau EM, Shichida Y. Functional role of internal water molecules in rhodopsin revealed by x-ray crystallography. Proc Natl Acad Sci. USA. 2002;99:5982-7.

8. Palczewski K, Kumasaka T, Hori T, Behnke CA, Motoshima H, Fox BA, et al. Crystal structure of rhodopsin: A G protein-coupled receptor. Science. 2000;289:739-45.

9. Foster KW, Saranak J, Dowben PA. Spectral sensitivity, structure and activation of eukaryotic rhodopsins: activation spectroscopy of rhodopsin analogs in Chlamydomonas. J Photochem Photobiol Biol. 1991;8:385-408.

10. Tha action of light on rhodopsin. Proc Natl Acad Sci USA. 1958

Copyright by Piotr Brzeziński, et al. This is an open-access article distributed under the terms of the Creative Commons Attribution License, which permits unrestricted use, distribution, and reproduction in any medium, provided the original author and source are credited.

Source of Support: Nil, Conflict of Interest: None declared. 